\title{
Experimental investigation and exergy analysis of an air heater with a solar concentrator used for drying processes
}

\author{
Housseyn Karoua ${ }^{1,2 *}$, Abdelhafid Moummi ${ }^{2,3}$, Abderrahmane Hamidat ${ }^{1}$, Noureddine Moummi ${ }^{3}$, Kamel Aoues ${ }^{3}$, Adel \\ Benchabane ${ }^{4}$, Ahmed Benchatti ${ }^{5}$ \\ ${ }^{1}$ Centre de Développement des Energies Renouvelables, CDER, Algiers 16340, Algeria \\ ${ }^{2}$ Laboratory of Civil engineering, Hydraulics, Sustainable development and Environment (LAR-GHYDE), University of \\ Biskra 07000, Algeria \\ ${ }^{3}$ Laboratoire de Génie Mécanique (LGM), Université de Biskra BP 145, Biskra 07000, Algeria \\ ${ }^{4}$ Laboratoire de Génie Energétique et Matériaux (LGEM) Biskra, Biskra 07000, Algeria \\ ${ }^{5}$ Laboratoire de Génie Mécanique, Université d’Amar Telidji, Laghouat 07000, Algeria
}

Corresponding Author Email: h.karoua@cder.dz

https://doi.org/10.18280/ijht.360303

Received: 20 Febraury 2018

Accepted: 5 September 2018

\section{Keywords:}

solar concentration, air heater, rectangular duct, exergy, experimental study

\begin{abstract}
In this paper, a solar air heater collector is developed and investigated. A concentrating feature of Linear Fresnel Reflector and the characteristics of flat plate air heaters (LFRAH) collectors are used. In this experimental study, three configurations of the absorber used to improve the thermal performance of LFRAH for the drying and the space heating processes, where two configurations of the absorber plate have different types of artificial roughness and the third configuration has a smooth absorber. The measured parameters are the ambient temperature, inlet and outlet temperatures of the air heater, the temperatures of the absorber, and the solar radiation intensity. The measurements performed at the same values of mass flow rate, 0.018 $\left(\mathrm{kg} . \mathrm{s}^{-1}\right)$. The introduction of the artificial roughness at the absorber plate allows having average air temperatures greater than $100^{\circ} \mathrm{C}$. The comparison of the thermal efficiency shows that the roughened absorbers improve the thermal efficiency by $62 \%$ compared to the smooth absorber.
\end{abstract}

\section{INTRODUCTION}

The increasing demand for energy consumption and the limited awareness among people about energy saving management led the Algerian government to introduce a range of preventive measures. The purpose behind such measures was to save the natural resources, control the importation bill, and protect the reserves of gas and oil. The high fluctuation on the global market which oil has known over the last years and the increase of electricity and gas prices by $50 \%$ [1] resulted in further rises in costs of oil derivatives, foodstuffs, and transport tickets. Moreover, the citizens' growing need for well-being and greater comfort urged the ministry of energy to launch awareness campaigns on how the reduce electricity consumption. The recommendations involved using economical electrical equipment, replacing the incandescent lamps and cheap air conditioners by others with a better quality, and reducing electricity consumption at peak times of consumption [2-3]. This situation precipitated the inevitable trend of using solar energy, an alternative resource that looks very encouraging with its availability of approximately 1700 $\mathrm{kWh} \cdot \mathrm{m}^{-2} \cdot \mathrm{yr}^{-1}$ in the North and $2263 \mathrm{kWh} \cdot \mathrm{m}^{-2} \cdot \mathrm{yr}^{-1}$ in the South of the country [4]. Therefore, the ministry of energy developed a program to make solar energy reaching more than $27 \%$ of national electricity production by 2030 [5].

Several studies have conducted in this field to simulate and optimize the heat transfer, the heat loss between the heat transfer fluid (HTF) and the absorber, which usually made from pipe, rectangular or trapezoidal duct. Other studies investigated the effect of shading and blocking between mirrors and the thermal efficiency [6-14].

S.S. Mathur et al. [15] made the first analytical study based on the same width of mirror elements. They used horizontal, flat vertical and tubular absorbers as three different configurations when the solar altitudes angle was maximal to investigate the distribution of the Local Concentration Ratio (LCR) on the absorbers. The results of both the analytical and the ray trace techniques were used in the discussion. They found that the peak value of LCR of the ray trace technique was lower by $16 \%$ and $19 \%$ in the case of distribution obtained by the analytical technique on the flat horizontal and flat vertical absorbers respectively. In addition, the distribution of LCR obtained on the tubular absorber by the analytical technique had a total spread of $74^{\circ}$. In another study [16], R.P. Goswami et al. give two different approaches with fixed and variation of the width of mirrors for designing a Linear Fresnel Reflector (LFR). Based on the method of Mathus et al, their research investigated the LCR with a triangular absorber configuration. As a result, they found that LFR with triangular absorber provides a better performance compared with flat vertical in terms of uniform concentration on the absorber. B.S. Negi et al. [17] carried out a detailed performance analysis of LFR with flat vertical absorber including the effect of various design parameters like the width and height of absorber from the mirrors element, the aperture diameter of the concentrator, the LCR. Two approaches have tested: the first allows a variation in the width of the mirrors element and the second uses equal width. The results showed that the first approach gives a better performance in terms of concentration on both of the surfaces of the absorber, but the design appears to be 
cumbersome from the practical point of view, and it requires mirror elements of varying width and too small to fabricate. However, in observing the LCR on the surface of the absorber, they found no uniform distribution in the first design while a uniform distribution noticed in the second design. B.S. Negi et al. [18] carried out an experimental study of optical and thermal performance; they used three identical tubular absorbers of copper with different absorptive coatings. The results demonstrated a significant advantage in the average optical efficiency with the selective MAXORB foil by $0.57 \%$ compared to 0.46 and $0.36 \%$ with the cobalt oxide and the ordinary black paint respectively. D. Feuermann and J.M. Gordon [19] conducted a simulation and experimental analysis of an installed nominally $220 \mathrm{~kW}$ system of two-stage LFR and found that the system delivers a yearly energy less by onefourth compared with trough collector. Mills and Morrison [20] presented an evaluation study of a compact LFR concept suitable for the large-scale solar field by using two receivers, one in each side of the reflector, and they have proposed a new absorber tube configuration using a purpose designed multibranched ray trace model. Moreover, A. Barbónet et al. [21] contributed with a theoretical and mathematical study to find the optimal design of a small-scale LFR. They analyzed 12 various configurations taking into account the frontal and lateral view. All aspects of design parameters including the number, the width, position of primary mirrors, length and location of the absorber were analyzed. Without addressing thermal and economic aspects, they presented a novel mathematical modelization of the mirror field width. Montes et al. [22] proposed and developed a thermal model on two dimensional of LFR. The model allows the possibility to simulate the performance of the receiver with different working fluids, as well as simulate the convective and radiative heat transfer in the receiver cavity. Wang et al. [23] made a simulation and theoretical analysis where an investigation of the concentrating performance conducted. The results showed a better optical efficiency of the bandfocus Fresnel lens compared with the linear lens. Besides in same field, Xu et al. [24] evaluated the performance of a direct vapor generation supercritical Organic Rankine Cycle (ORC) coupled with LFR. They presented a modeling study of the working fluid for middle-high temperature between $\left(150^{\circ} \mathrm{C}\right.$ $\left.350^{\circ} \mathrm{C}\right)$. The results showed that the higher overall efficiency found was about $19.65 \%$, whereas the best working fluid was the cyclohexane for the supercritical organic Rankine cycle. Pino et al. [25] conducted an experimental validation of a design and thermal model to simulate the optical and thermal performances of an LFR system for the cooling process. The difference between the modelling and real value of the heat absorbed by the water was found less than $7 \%$, although, the error between measurement and calculate results was less than $1 \%$ when output temperature is considered. R. Abbas and J.M. Martínez-Val [26-27] presented an analytical study and a comprehensive optical characterization using different widths and shifts of mirrors [28] to obtain a coherent design and a significant efficiency at the lowest possible cost. After one year of ray tracing simulation testing on their design model, they achieved an increase in radiation collecting efficiency compared to other model designs. Other studies carried out to analyze the use of different mirrors shapes and different positions aimed at characterizing the concentration process [29]. Another experimental study carried out by L.S. Panna et al. [30] used a trapezoidal cavity absorber in LFR with two types of pipe absorber: round and rectangular pipes. The experimental results at different concentration ratio, revealed that the thermal efficiency of around pipe is almost $8 \%$ higher compared to the rectangular pipe absorber. Further, N, Velázquez et al. [31] tried to understand the effect of design parameters on the thermal performance of the refrigeration system through a numerical simulation of an LFR use as a solar cooling. The analysis of the heat balance in absorber developed a theoretical model, then validated by experimental results. H. Esen [32] studied two absorbers with several obstacles and one without obstacles under different values of mass flow rate of air. Besides, R, Pujol-Nadal, and V, Martinez-moll [33] used 3D ray-tracing tools to construct an LFR collector with fixed mirrors and trapezoidal rotation absorber. This collector was destined for medium range temperature applications with easy integration onto building roofs, and they confirmed by numerical model results of an experimental study. Furthermore, many researches carried out on flat plate collectors and studied the role of artificial roughening on the thermal performance of these types of solar collectors [34-39].

Labed et al. and S. Youcef-Ali [40-41] carried out an experimental investigation to study the critical role of the use of roughness under different air mass flow with three types of roughness including the type used in the present study. O. Mahfoud et al., through a dynamic and thermal simulation, found that the use of roughness increases the heat transfer by $23 \%$ [42] in the flat plate solar air heater collector. Varun et al. [43] presented a review of different types of roughness geometry used in solar air heater with their correlation of heat transfer coefficient, friction factor and the related parameters developed by the authors. It shows that the use of artificial roughness has an important impact on enhancing the heat transfer in the rectangular duct of the solar air heater. Karim and Hawlader [44] conducted an experimental study of three types of solar air heaters used for the drying application. They found that the $\mathrm{v}$-corrugated collector has $12 \%$ higher efficiency than the flat plate collector does.

This paper presents an experimental study carried out on the thermal performance of a solar air heater collector, which uses the concentrating feature of LFR. Thus, an experimental study investigated the effects of the use of different artificial roughness on the thermal efficiency of LFRAH. The outlet temperatures of all configurations compared experimentally at the same mass flow rate.

\section{MATERIALS AND METHODS}

This paper provides an experimental investigation with the objective of improving the performances of a solar air heater blended with the features of Linear Fresnel Reflector (LFR). Therefore, a small-scale LFR solar concentrator with fixed mirrors manufactured and tested (Fig.1). The heat fluid transfer flowing inside a rectangular duct placed in the focal line of the LFR. The rectangular duct is equipped with three different absorber plates: a) absorber plate with twisted roughness as configuration one (conf1), b) absorber plate with rectangular roughness as configuration two (conf2), and c) smooth absorber plate as the third configuration (conf3). All measurements data are effected under the same environment conduction and constant flow rate of $0.018\left(\mathrm{~kg} . \mathrm{s}^{-1}\right)$ supplied by a radial fan. The measurements parameters are the global solar radiation, the ambient temperature, the inlet and outlet temperatures of the heat transfer fluid (air) and the absorber 
plate temperatures.

\section{MODELING ANALYSIS}

\subsection{Energy analysis}

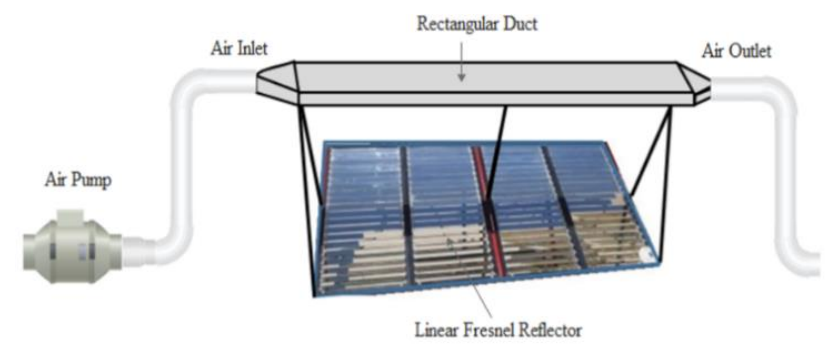

Figure 1. Rectangular duct with a Linear Fresnel Reflector

Usually, the application of the solar air heater is in the building heating, industrial process, and air conditioning. It means that it operates under quasi-steady-state conditions that allow describing the performance of an energy balance that indicates the distribution of concentrate solar energy into useful energy gain, thermal losses, and stored energy.

$\phi_{c}=\phi_{u}+\phi_{l}+\phi_{s t}$

where; $\phi_{c}$ is the Concentrate solar energy, $\phi_{u}$ is the useful energy gain, $\phi_{l}$ is the thermal energy losses, $\phi_{s t}$ is the stored energy

By neglecting the stored energy, the energy balance became:

$$
\phi_{c}=\phi_{u}+\phi_{l}
$$

Then we can start writing:

$\phi_{u}=\phi_{l}-\phi_{c}$

In the right hand, the useful heat gain can be express as;

$\phi_{u}=\dot{m} C p\left(T_{f s}-T_{f e}\right)$

The thermal efficiency of the collector indicated by the ratio of the useful power conveyed through the fluid, by the solar energy concentrated by the mirrors of the LFR given the $\operatorname{Eq}(5)$ :

$$
\eta_{t h}=\frac{\dot{m} C p\left(T_{f s}-T_{f e}\right)}{\left[\tau_{v} \alpha_{a b s}(1.01) \rho \gamma I_{g} C R\right] S_{c a p}}
$$

where: $\dot{m}$ is the mass flow rate of the air, $C p$ is the specific heat of air, $T_{f s}$ and $T_{f e}$ are the inlet and the outlet temperatures of the air, respectively, $\tau_{v}$ is the optical coefficient of transmission of the glazing $0.84(\%), \alpha_{a b s}$ is the thermal diffusivity of the absorber, $\rho$ is the reflective of mirrors, $\gamma$ is dimensionless temperature, $I_{g}$ is solar global irradiance incident on LFR, $C R$ is solar concentrated energy, $S_{c a p}$ is the collector concentration surface.

\subsection{Exergy analysis}

Exergy defined as the maximum useful work potential of a system. Exergy analysis can used to design more efficient energy systems. Exergy balance for open systems under the steady-state conditions can give as follows;

$$
\sum \dot{E} x_{i n}-\sum \dot{E} x_{o u t}=\sum \dot{E} x_{d e s t}
$$

$$
\sum\left(1-\frac{T_{e}}{T_{s}}\right) \dot{Q}_{s}-\dot{w}+\sum \dot{m}_{\text {in }} \psi_{\text {in }}-\sum \dot{m}_{\text {out }} \psi_{\text {out }}=\dot{E} x_{\text {dest }}
$$

where

$$
\begin{aligned}
& \psi_{\text {in }}=\left(h_{\text {in }}-h_{e}\right)-T_{e}\left(s_{\text {in }}-s_{e}\right) \\
& \psi_{\text {out }}=\left(h_{\text {out }}-h_{e}\right)-T_{e}\left(s_{\text {out }}-s_{e}\right)
\end{aligned}
$$

By substitute Eq. (8) and Eq. (9) into Eq. (7) yields;

$\sum\left(1-\frac{T_{e}}{T_{s}}\right) \dot{Q}_{s}-\dot{m}\left[\left(h_{\text {out }}-h_{\text {in }}\right)-T_{e}\left(s_{\text {out }}-s_{\text {in }}\right)\right]=\dot{E} x_{\text {dest }}$

where $T_{s}$ is the apparent sun temperature, which is approximately set equal to $6000 \mathrm{~K}$ and $\dot{Q}_{s}$ is the solar energy rate absorbed by the absorber plate and it is evaluated by the following relation [32];

$\dot{Q}_{s}=I A_{c}(\tau \alpha)$

The enthalpy and entropy changes of the air in the rectangular duct expressed by

$\Delta h=h_{\text {out }}-h_{\text {in }}=C p\left(T_{f s}-T_{f e}\right)$

$\Delta s=s_{\text {out }}-s_{\text {in }}=C p \ln \frac{T_{f s}}{T_{f e}}-R \ln \frac{P_{\text {out }}}{P_{\text {in }}}$

Substituting Eqs. (11)-(13) in Eq. (10), it may be rewritten as follows ;

$$
\begin{aligned}
& \sum\left(1-\frac{T_{e}}{T_{s}}\right) I A_{c}(\tau \alpha)-\dot{m} C p\left(T_{f s}-T_{f e}\right)+\dot{m} C p T_{e} \ln \frac{T_{f s}}{T_{f e}} \\
& -\dot{m} R T_{e} \ln \frac{P_{o u t}}{P_{\text {in }}}=\dot{E} x_{d e s t}
\end{aligned}
$$

The irreversibility $\dot{E} x_{\text {dest }}$ can evaluated from the following equation:

$$
\dot{E x} x_{d e s t}=T_{e} S_{g e n}
$$

The second law efficiency calculated as;

$\eta_{\text {exergy }}=1-\frac{T_{e} S_{g e n}}{\left[1-\left(T_{e} / T_{s}\right)\right] \dot{Q}_{s}}$ 


\section{CASE STUDIES}

For the three configurations studied, the comparison and the analysis of the experimental results are carried out during three days with a relatively close solar radiation. Fig. 2 illustrates the solar radiation used for the three configurations.

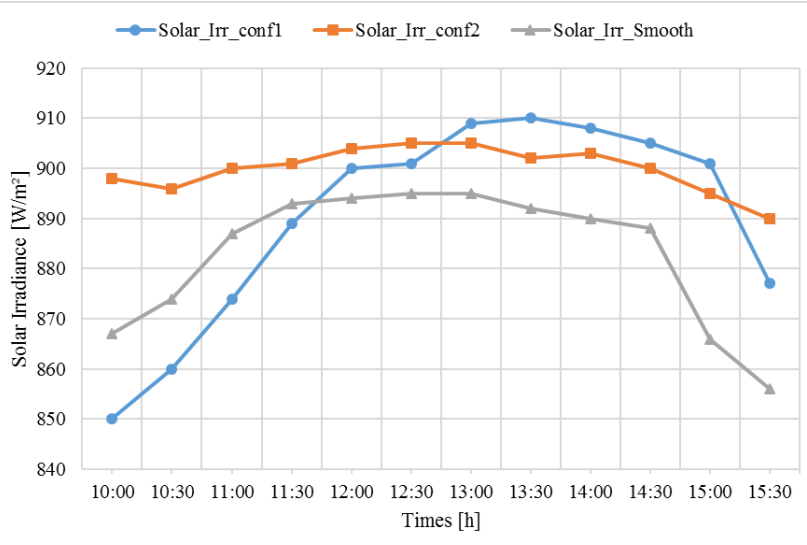

Figure 2. Solar radiance for the three configurations

\subsection{The first case study}

In the first case, the used configuration of an artificial roughness shown in Fig. 3, which imitated from the cooling equipment for a microprocessor placed on HP computers. The distribution of the roughness allows the excellent spread of air inside the rectangular duct, thus contributing to stimulating the heat exchange between the air heater and the absorber plate.

On the other hand, a significant loss has found between the inlet and the outlet velocity of the air heater by $50 \%$ compared with the smooth configuration.

\subsection{The second case study}

The second configuration of an artificial roughness is selected from a study prepared previously by A. Labed et al. and S. Youcef-Ali [40-41, 45-46]. The role of this roughness is the spread of air inside the rectangular duct absorber and the stimulation of the heat transfer between the air heater and the absorber Fig. 4. For the second configuration, the results show that the loss of air velocity between the inlet and outlet is $21 \%$ compared with the smooth configuration.

\subsection{The third case study}

The smooth configuration is a flat plate absorber without any roughness. It gives us a global idea of what can the roughness add to improve the performance of the solar air heater and the heat exchange between the absorber and the air heater. Detailed mathematical modeling can found in Duffie and Beckman [47].

\section{DESCRIPTION OF THE EXPERIMENTAL DEVICE}

\subsection{Basic Structure and Materials}

A small-scale solar concentrator based on Fresnel fixed mirrors designed and made as shown in Fig. 1. The LFRAH consists of two parts, the linear Fresnel Reflector, and the rectangular duct. This latter placed in the focal line of the collector, where the flow rate of the air inside the duct supplied by an air pump. A single transparent glazing glass with $3 \mathrm{~mm}$ of thickness used. More information about material dimensions and characterizations provided in Table 1.

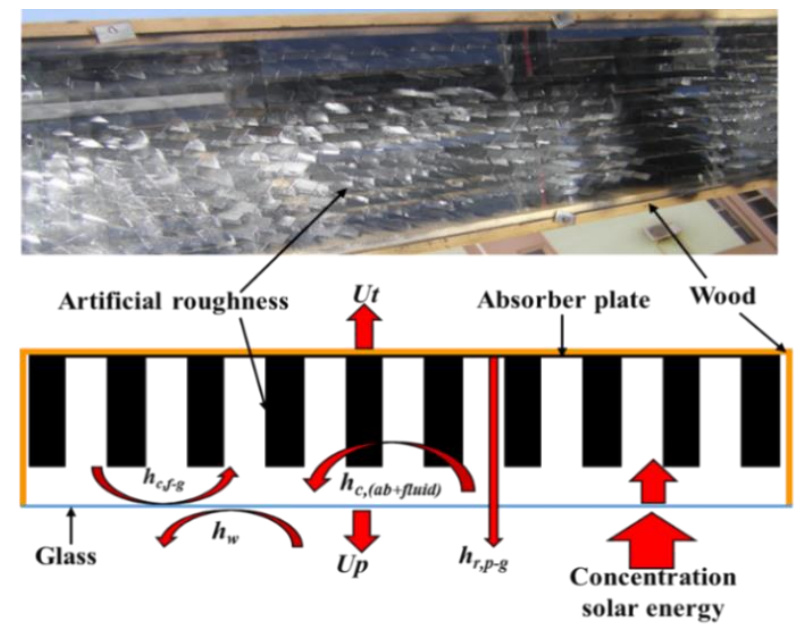

Figure 3. Photographic of the rectangular duct with the schema of the heat exchange conf1

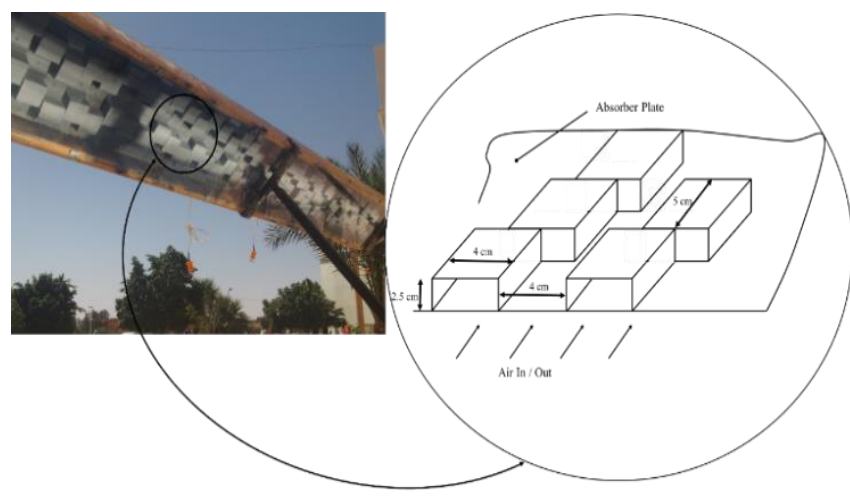

Figure 4. Photographic of the rectangular duct with the schema of conf2

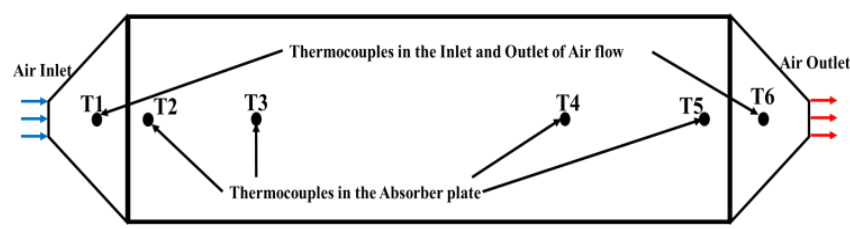

Figure 5. Illustration of the thermocouple position

The testing system consists of the following components:

(1) The LFR collector and the rectangular duct moving together from the east to the west with a tracking system to flow the trajectory of the sun (Fig. 1).

(2) An air pump used to ensure a constant flow rate of the air inside the rectangular duct.

(3) Absorber plate roughened by twisted and rectangular roughness, compared with the smooth absorber (Fig.3, 4).

(4) Thermocouples placed at identical positions along the direction of flow in the inlet and the outlet of the duct to measure the temperature of the air heater. Moreover, other thermocouples placed into the absorber plate to measure the temperature of the absorber as shown in Fig. 5. 


\subsection{Instruments of measurement}

The measurement data registered at an average interval of $15 \mathrm{~min}$. The devices used in the experimental measures were:

(1) The temperatures, thermocouples type k.

(2) Solar radiation intensity, Kipp and Zonen pyranometer CM 11 adaptable to the horizontal and inclined surface.

(3) The airflow rate and wind velocity, Kimo Multifunction anemometer model VT300.

Presented in Table 2, the list of instruments of measurements employed in this study and their relative fullscale accuracy and operating range.

The geometrical dimensions and elements components given in Table 1.

Table 1. Dimensions of LFR and the rectangular duct

\begin{tabular}{|c|c|c|}
\hline Designation & $\begin{array}{c}\text { Symbols/Design } \\
\text { materials }\end{array}$ & values \\
\hline Length of the rectangular duct (m) & L / Wood & 2.32 \\
\hline Width of the collector $(\mathrm{m})$ & Wth / Steel & 1.18 \\
\hline Width of mirrors (m) & Glass & 0.10 \\
\hline Focal distance $(\mathrm{m})$ & $f$ & 1.00 \\
\hline Width of the rectangular duct (m) & $l /$ Wood & 0.23 \\
\hline Thickness of rectangular duct (m) & e / Wood & 0.05 \\
\hline Number of mirrors & $\mathrm{nm} /$ Glass & 80 \\
\hline \multicolumn{3}{|l|}{ First configuration } \\
\hline Height of artificial roughness (m) & $\mathrm{a}_{\text {art }} /$ Steel & 0.045 \\
\hline $\begin{array}{l}\text { Space between artificial } \\
\text { roughness }(\mathrm{m})\end{array}$ & bart & 0.01 \\
\hline \multicolumn{3}{|l|}{ Second configuration } \\
\hline Height of artificial roughness (m) & $\mathrm{a}_{\text {art }} /$ Steel & 0.025 \\
\hline $\begin{array}{c}\text { Space between artificial } \\
\text { roughness }(\mathrm{m})\end{array}$ & $b_{\text {art }}$ & 0.04 \\
\hline Length of artificial roughness (m) & $\mathrm{c}_{\text {art }} /$ Steel & 0.05 \\
\hline
\end{tabular}

\section{UNCERTAINTY ANALYSIS}

The tests of uncertainties can inverse from the chosen test device, requirement, accuracy, reading, observation, and ambient conditions. Uncertainty intervals of measuring instruments used for experimentation previously presented. Considering the intervals of uncertainty, the use of EES (engineering equation solver) to estimate the uncertainty of each device is very easy. The purpose of this command is to calculate how the uncertainties in each of the measured variables propagate into the value of the calculated quantity, Y. The method for determining this uncertainty propagation is described in NIST Technical Note 1297 (Taylor B.N. and Kuyatt, C.E., Guidelines for Evaluating and Expressing the Uncertainty of NIST Measurement Results, National Institute of Standards and Technical Technology Note 1297, 1994). Assuming the individual measurements are uncorrelated and random, the uncertainty in the calculated quantity can be determined as follows

$U_{Y}=\sqrt{\sum_{i}\left(\frac{\partial Y}{\partial X_{i}}\right)^{2} U_{i}^{2}}$
Table 2. Accuracy and operating range of instruments of measurement

\begin{tabular}{|c|c|c|c|}
\hline Instrument & Model & Accuracy & Range reading \\
\hline $\begin{array}{l}\text { Digital k-type } \\
\text { thermocouples }\end{array}$ & Type k & $\pm 2.2^{\circ} \mathrm{C}$ & $0-400{ }^{\circ} \mathrm{C}$ \\
\hline Pyranometer & $\begin{array}{l}\text { Kipp and } \\
\text { Zonen } \\
\text { pyranometer } \\
\text { CM } 11\end{array}$ & $1 \%$ & 0-4000 W.m $\mathrm{m}^{-2}$ \\
\hline $\begin{array}{c}\text { Kimo } \\
\text { Multifunction } \\
\text { anemometer }\end{array}$ & VT300 & $\begin{array}{c}0.15 \text { to } 3 \\
\mathrm{~m} . \mathrm{s}^{-1}: \pm 3 \% \\
\text { of reading } \\
\pm 0.05 \mathrm{~m} . \mathrm{s}^{-1}\end{array}$ & 0.15 to $30 \mathrm{~m} \cdot \mathrm{s}^{-1}$ \\
\hline
\end{tabular}

\section{EXPERIMENTAL RESULTS AND DISCUSSION}

This section presents the experimental investigation results and compares the performance of the solar air heater in the three configurations of the absorber under the same environmental conditions and equal flow rates. In order to increase the heat removal coefficient from the absorber plate to the flowing air, two types of artificial roughness used in the first and second configurations. It can see in the evolutions of the outlet temperatures of the flowing air as shown in Fig. 6 and 7 where the temperatures recorded here high values ranging from $92-110^{\circ} \mathrm{C}$, and $100-150^{\circ} \mathrm{C}$ in the first and second configuration respectively, compared to the smooth configuration. Consequently, the heat exchange between the air flowing in the rectangular duct and the absorber plate was very weak, and the temperatures of the air heater found less than $100^{\circ} \mathrm{C}$ as shown in Fig. 8 .

Moreover, the compared of the temperatures of the absorber in the three configurations presented clearly in (Fig. 9) that the absorber plate in the smooth configuration reached the highest temperatures compared with the first and second configurations. This remains expected, taking into account the weakness of heat exchange due to the lack of artificial roughness, which increases the convection heat exchange with the air. Therefore, a significant increase is recorded in the temperature of the absorber plate in the smooth configuration, and the temperatures reach the maximum values 130,150 and $200^{\circ} \mathrm{C}$ in the first, second and smooth configurations respectively.

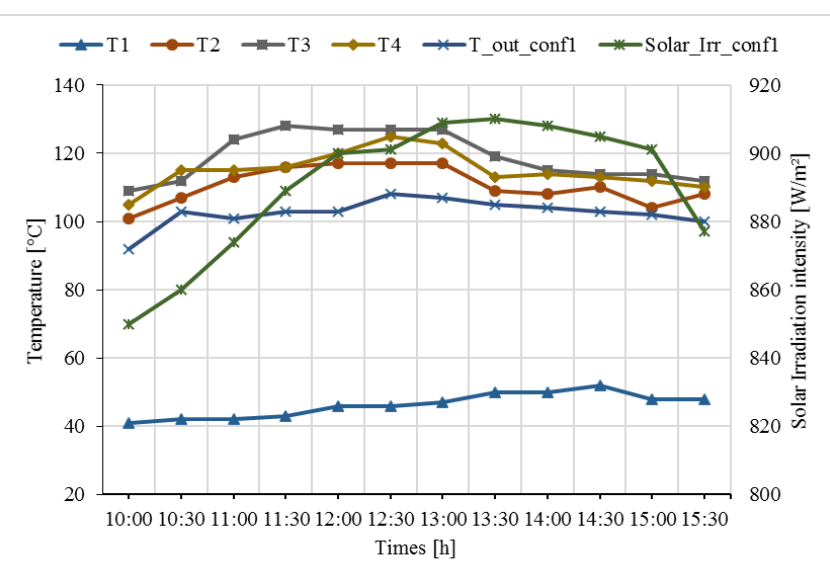

Figure 6. Variation of the temperatures by time conf1

where U represents the uncertainty of the variable. 
As expected in the smooth configuration, without an artificial roughness in the absorber, the outlet temperatures of the air heater reached here least values between $90-96^{\circ} \mathrm{C}$ (Fig. 8 ). While in the same case, the highest values in temperatures of the absorber plate recorded in by $87,179,162$ and $200^{\circ} \mathrm{C}$ at 12:30 in the thermocouples $\mathrm{T} 1, \mathrm{~T} 2, \mathrm{~T} 3$ and $\mathrm{T} 4$ respectively. However, in the first and second configurations, the artificial roughness increases the coefficient of heat transfer by convection between the absorber plate and the air heater. A signification increases in the air heater temperatures registered in the first and second configurations from 92 at 10:00 to $108^{\circ} \mathrm{C}$ at $12: 30 \mathrm{~min}$ and $118^{\circ} \mathrm{C}$ at $10: 00$ to $150^{\circ} \mathrm{C}$ at $13: 00$ respectively.

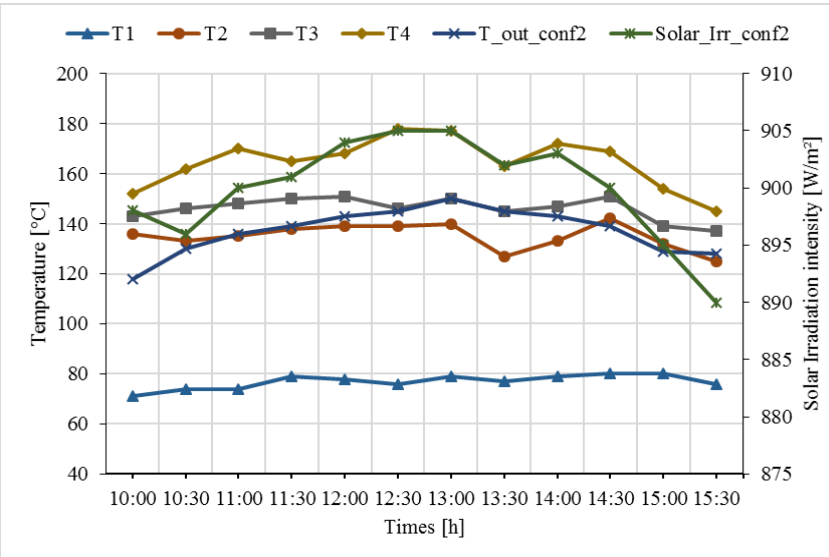

Figure 7. Variation of temperatures by time conf2

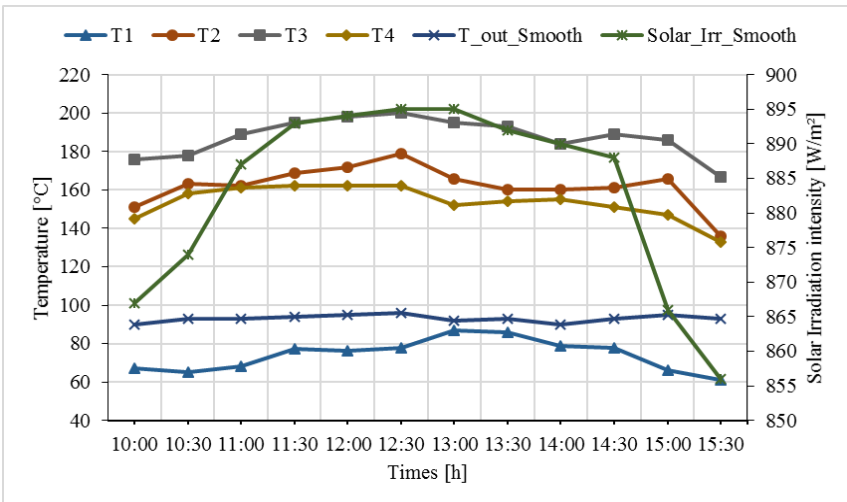

Figure 8. Variation of temperatures by time conf3

Presented in Fig. 9 is the evolution of the flowing air outlet temperatures of the smooth configurations. It is clear that the efficiency of the second configuration is the best one with around $70 \%$ from $11: 00$ to $14: 30$. This type of roughness proved useful by having the best thermal exchange coefficient between air and the absorber plate. This last recorded the highest temperature compared to the second configuration, which reached in mean efficiency by $66 \%$ from 11:00 to $15: 30$. The smooth configuration reaches the lowest values of the thermal efficiency by $45 \%$ on average.

According to Table 3, the average temperature has a reduction by 0.07 and $0.33 \%$ in the absorber for the second and the first configurations respectively compared with the smooth configuration. Moreover, the upper temperature reached in thermocouple three on the smooth configuration by $188^{\circ} \mathrm{C}$ followed by $165^{\circ} \mathrm{C}$ on the thermocouple 4 and $119^{\circ} \mathrm{C}$ on the thermocouple 3 in the second and first configurations respectively.

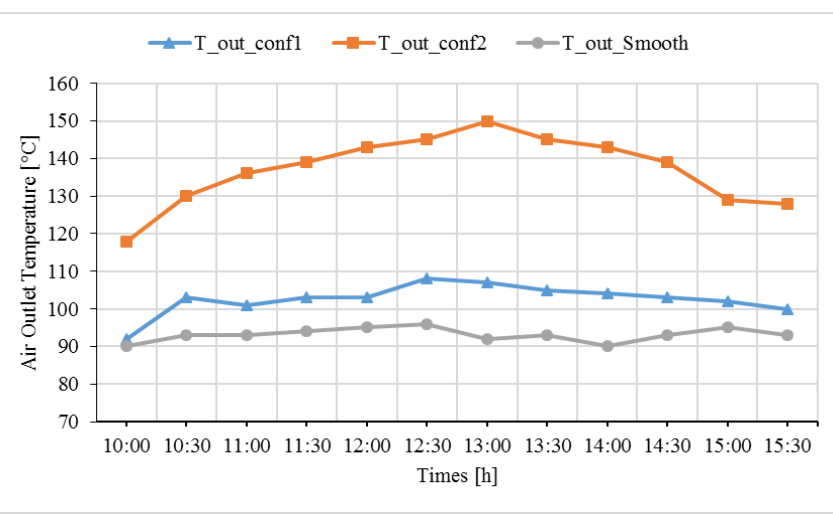

Figure 9. Variation of air outlet temperature by the time

Presented in Fig. 10 is the variation of the thermal efficiency of the three configurations. It is clear that the best thermal efficiency recorded in the first and the second configurations, where the value reached $65 \%$ and $75 \%$ in the first and second configurations respectively. This increase in the efficiency is due to the role of the artificial roughness in improving the heat exchange between the flowing air and the absorber. Therefore, the weakest thermal efficiency recorded in the third configuration by $45 \%$, while the loss of the heat considered from the bottom and the side of the rectangular absorber duct.

Table 3. Variation of the absorber plate temperatures

\begin{tabular}{|c|c|c|c|c|c|c|c|c|c|c|}
\hline & $\begin{array}{l}\text { 塄 } \\
\text { 芭 }\end{array}$ & 居 & 泀 & 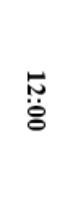 & 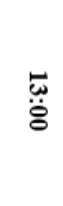 & 䗆 & 范 & 莣 & 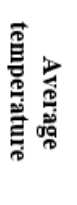 & 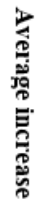 \\
\hline \multirow{4}{*}{ 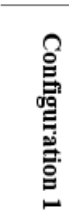 } & T1 & 41 & 42 & 46 & 47 & 50 & 48 & 48 & 46 & \\
\hline & $\mathrm{T} 2$ & 101 & 113 & 117 & 117 & 108 & 104 & 108 & 111 & 0 \\
\hline & $\mathrm{T} 3$ & 109 & 124 & 127 & 127 & 115 & 114 & 112 & 119 & ¿ \\
\hline & $\mathrm{T} 4$ & 105 & 115 & 120 & 123 & 114 & 112 & 110 & 115 & \\
\hline \multirow{4}{*}{ 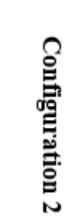 } & $\mathrm{T} 1$ & 71 & 74 & 78 & 79 & 79 & 80 & 76 & 77 & \\
\hline & $\mathrm{T} 2$ & 136 & 135 & 139 & 140 & 133 & 132 & 125 & 135 & $\circ$ \\
\hline & T3 & 143 & 148 & 151 & 150 & 147 & 139 & 137 & 146 & ஃீ \\
\hline & $\mathrm{T} 4$ & 152 & 170 & 168 & 177 & 172 & 154 & 145 & 165 & \\
\hline \multirow{4}{*}{ 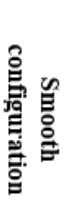 } & $\mathrm{T} 1$ & 67 & 68 & 76 & 86 & 79 & 66 & 61 & 75 & \\
\hline & $\mathrm{T} 2$ & 151 & 162 & 172 & 166 & 160 & 160 & 136 & 162 & \\
\hline & T3 & 176 & 189 & 198 & 195 & 184 & 186 & 167 & 188 & \\
\hline & $\mathrm{T} 4$ & 145 & 161 & 162 & 152 & 155 & 147 & 133 & 154 & \\
\hline
\end{tabular}

Fig. 11 shows a comparison of the exergetic between the conf1, conf2, and conf3 of solar air heater with mass flow rate equal $0.018 \mathrm{~kg} . \mathrm{s}^{-1}$ mass flow rate. The maximum values of exergy efficiency are found in the configuration of rectangular roughness (conf 2 ) by more than $0.2 \%$ after midday at $13: 00$, and the values increase from sunrise to midday and decrease after that until they reach the minimum with the sunset about $0.1 \%$ at $10: 00$ and 15:30. However, the exergy values of the 
air heater with conf 1 and conf 3 decrease significantly by about $0.1 \%$ in conf 1 and lower than $0.05 \%$ in the last configuration.

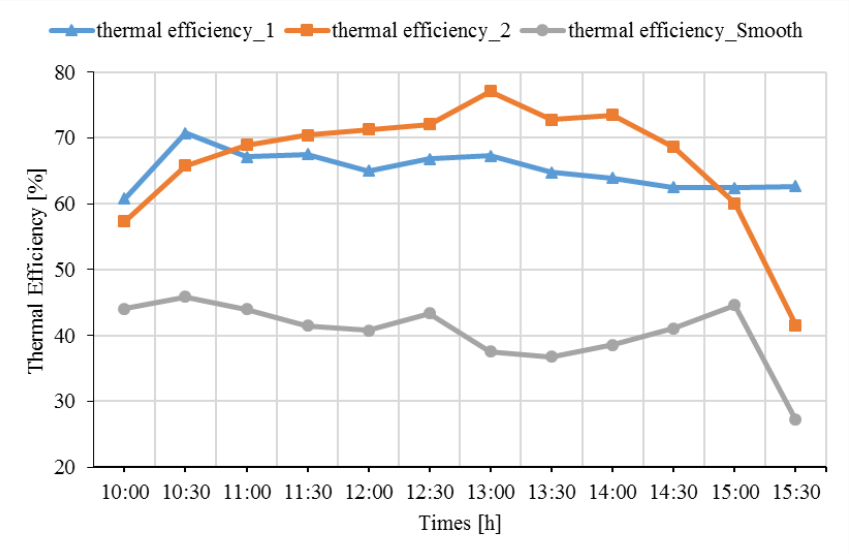

Figure 10. Variation of the thermal efficiency by the time

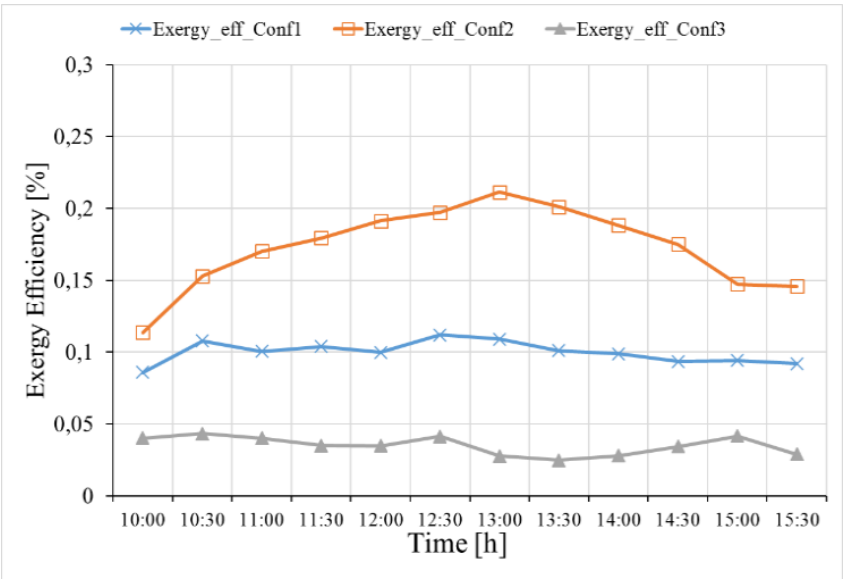

Figure 11. Variation of the exergy efficiency by the time

In the main, the results show that the efficiency of the solar air heater heavily depends on the type of artificial roughness and solar radiation. The study shows that the solar air heater thermal efficiency improved with the use of the artificial roughness and the best values recorded using the rectangular roughness configuration.

\section{CONCLUSION}

In the present work, an experimental investigation of the performance of solar air heater blended with the solar concentrating feature of Linear Fresnel Reflector conducted in order to exploit it in the field of heating space and drying of agricultural products. To that end, an experimental investigation conducted for three configurations of the rectangular absorber duct, which placed in the focal line of Linear Fresnel Reflector to improve the performance of this new solar air heater.

According to the results obtained in this study, it becomes evident that the use of artificial roughness increases the heat transfer coefficient, which enhances the performance of the solar air heater compared with the smooth case. Significant average rises of heat transfer coefficient are achieved by (10\%) and $(47 \%)$ for the first and second artificial roughness respectively. Moreover, an average increase in the thermal efficiency by $(58 \%)$ and $(62 \%)$ in the first and second configurations respectively is registered and compared with the smooth case. Through these results, it concluded that the second artificial roughness is the best configuration and gives us the best outlet temperatures.

In conclusion, the blending of the two technologies studied in this paper allows us to reach the temperature of the air heater usually upper than $100^{\circ} \mathrm{C}$, a degree which is not easy to achieve with the conventional flat plate air heater collector.

\section{ACKNOWLEDGEMENTS}

The authors are very thankful to everyone who contributed to the completion of this study, especially mention, M. Saber Guenifi (Engineering on Mechanical at the University of Mohamed Khider of Biskra) and M. Mohammed Taher Baissi (Master on Mechanical at the University of Mohamed Khider of Biskra) for their technical assistance.

\section{REFERENCES}

[1] JORADP. (2010). Official Journal of the People's Democratic Republic of Algeria. Law $n{ }^{\circ} 10-95$ of 17 March 2010 laying down the economic rules for network connection fees and other actions necessary to satisfy electricity and gas demand from customers. https://www.joradp.dz/FTP/jo-

francais/2010/F2010019.pdf

[2] Eddine BT, Salah MM. (2012). Solid waste as renewable source of energy: current and future possibility in Algeria. International Journal of Energy Environmental Engineering 3(1): 17. https://doi.org/10.1186/22516832-3-17

[3] Missoum M, Hamidat A, Loukarfi L, Abdeladim K. (2014). Impact of rural housing energy performance improvement on the energy balance in the North-West of Algeria. Energy and Buildings 85: 374-388.

[4] Stambouli AB. (2011). Promotion of renewable energies in Algeria: strategies and perspectives. Renewable and Sustainable Energy Reviews 15: 1169-1181. https://doi.org/10.1016/j.rser.2010.11.017

[5] MEM (Ministère de l'énergie et des mines). (2015). Agence Nationale pour la Promotion et Rationalisation de l'Utilisation de l'énergie (APRUE), Energy Efficiency Development Program until 2030. www.aprue.org.dz

[6] Cagnoli M, Mazzei D, Procopio M, Russo V, Savoldi L, Zanino R. (2018). Analysis of the performance of linear Fresnel collectors: Encapsulated vs. evacuated tubes. Solar Energy 164: 119-138. https://doi.org/10.1016/j.solener.2018.02.037

[7] Cucumo MA, Ferraro V, Kaliakatsos D, Mele M, Nicoletti. F. (2017). Law of motion of reflectors for a linear Fresnel plant. International Journal of Heat and Technology 35: S78-S86. https://doi.org/10.18280/ijht.35Sp0111

[8] Zhu G. (2017). New adaptive method to optimize the secondary reflector of linear Fresnel collectors. Solar Energy 144: 117-126. https://doi.org/10.1016/j.solener.2017.01.005

[9] Chaitanya Prasad GS, Reddy KS, Sundararajan T. (2017). Optimization of solar linear Fresnel reflector system with secondary concentrator for uniform flux distribution over 
absorber tube. Solar Energy 150: 1-12 http://dx.doi.org/10.1016/j.solener.2017.04.026

[10] Regue MH, Benchatti T, Medjelled A, Benchatti A. (2014). Improving the performances of a solar cylindrical parabolic dual reflection Fresnel miror (experimental part). International Journal of Heat and Technology. 32(1-2): 171-178.

[11] Moghimi MA, Craig KJ, Meyer JP. (2015). Optimization of a trapezoidal cavity absorber for the Linear Fresnel Reflector. Solar Energy 119: 343-361. http://dx.doi.org/10.1016/j.solener.2015.07.009

[12] Zhu G, Wendelin T, Wagner MJ, Kutscher C. (2014). History, current state, and future of linear Fresnel concentrating solar collectors. Solar Energy 103: 639652. http://dx.doi.org/10.1016/j.solener.2013.05.021

[13] Sharma V, Nayak JK, Kedare S. B. (2015). Effects of shading and blocking in linear Fresnel reflector field. Solar Energy 113: 114-138. http://dx.doi.org/10.1016/j.solener.2014.12.026

[14] Lin M, Sumathy K, Dai YJ, Wang RZ, Chen Y. (2013). Experimental and theoretical analysis on a linear Fresnel reflector solar collector prototype with $\mathrm{V}$-shaped cavity receiver. Applied Thermal Engineering 51(1): 963-972. https://doi.org/10.1016/j.applthermaleng.2012.10.050

[15] Mathur SS, Kandpal TC, Negi BS. (1991). Optical design and concentration characteristics of linear Fresnel reflector solar concentrators-II. Mirror elements of equal width. Energy Conversion and Management 31(3): 221-232. https://doi.org/10.1016/0196-8904(91)90076$\mathrm{U}$

[16] Goswami RP, Negi BS, Sehgal HK, Sootha GD. (1990). Optical designs and concentration characteristics of a linear Fresnel reflector solar concentrator with a triangular absorber. Solar Energy Materials 21(2): 237251. http://dx.doi.org/10.1016/0165-1633(90)90057-8

[17] Negi BS, Kandpal TC, Mathur SS. (1990). Designs and performance characteristics of a linear Fresnel reflector solar concentrator with a flat vertical absorber. Solar \&

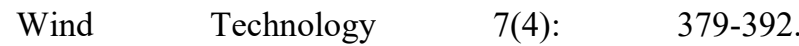
http://dx.doi.org/10.1016/0741-983X(90)90023-U

[18] Cucumo M, Ferraro V, Kaliakatsos D, Mele M, Nicoletti F. (2016). Calculation model using finite-difference method for energy analysis in a concentrating solar plant with linear Fresnel reflectors. International Journal of Heat Technology 34: S337-S345. https://doi.org/10.18280/ijht.34S221

[19] Feuermann D, Gordon J. (1991). Analysis of a two-stage linear Fresnel reflector solar concentrator. Journal of Solar Energy Engineering 113(4): 272-279. http://dx.doi.org/10.1115/1.2929973

[20] Mills DR, Morrison GL. (2000). Compact linear Fresnel reflector solar thermal power plants. Solar Energy 68(3): 263-283. 092X(99)00068-7

[21] Barbón A, Barbón N, Barbón L, Otero JA. (2016). Theoretical elements for the design of a small scale Linear Fresnel Reflector: Frontal and Lateral views. Solar Energy 132: 188-202. https://doi.org/10.1016/j.solener.2016.02.054

[22] Montes MJ, Barbero R, Abbas R, Rovira A. (2016). Performance model and thermal comparison of different alternatives for the Fresnel single-tube receiver. Applied Thermal Engineering 104(Supplement C): 162-175. https://doi.org/10.1016/j.applthermaleng.2016.05.015
[23] Wang G, Chen Z, Hu P, Cheng X. (2016). Design and optical analysis of the band-focus Fresnel lens solar concentrator. Applied Thermal Engineering 102(Supplement C): 695-700. https://doi.org/10.1016/j.applthermaleng.2016.04.030

[24] Xu G, Song G, Zhu X, Gao W, Li H, Quan Y. (2015). Performance evaluation of a direct vapor generation supercritical ORC system driven by linear Fresnel reflector solar concentrator. Applied Thermal Engineering 80(Supplement C): 196-204. https://doi.org/10.1016/j.applthermaleng.2014.12.071

[25] Pino FJ, Caro R, Rosa. F, Guerra J. (2013). Experimental validation of an optical and thermal model of a linear Fresnel collector system. Applied Thermal Engineering 50(2):

$1463-1471$. https://doi.org/10.1016/j.applthermaleng.2011.12.020

[26] Abbas R, Martínez-Val JM. (2015). Analytic optical design of linear Fresnel collectors with variable widths and shifts of mirrors. Renewable Energy 75: 81-92. http://dx.doi.org/10.1016/j.renene.2014.09.029

[27] Abbas R, Martínez-Val JM. (2017). A comprehensive optical characterization of linear Fresnel collecto RS by means of an analytic study. Applied Energy 185: 11361151. http://dx.doi.org/10.1016/j.apenergy.2016.01.065

[28] Abbas R, Muñoz-Antón J, Valdés M, Martínez-Val JM. (2013). High concentration linear Fresnel reflectors. Energy Conversion and Management 72: 60-68. http://dx.doi.org/10.1016/j.enconman.2013.01.039

[29] Abbas R, Montes MJ, Piera M, Martínez-Val J. (2012). Solar radiation concentration features in Linear Fresnel Reflector arrays. Energy Conversion and Management 54(1):

http://dx.doi.org/10.1016/j.enconman.2011.10.010

[30] Singh PL, Sarviya RM, Bhagoria JL. (2010). Thermal performance of linear Fresnel reflecting solar concentrator with trapezoidal cavity absorbers. Applied Energy 87(2): 541-550. http://dx.doi.org/10.1016/j.apenergy.2009.08.019

[31] Velázquez N, García-Valladares O, Sauceda D, Beltrán R. (2010). Numerical simulation of a Linear Fresnel Reflector Concentrator used as direct generator in a Solar-GAX cycle. Energy Conversion and Management 51(3): 434-445. http://dx.doi.org/10.1016/j.enconman.2009.10.005

[32] Esen H. (2008). Experimental energy and exergy analysis of a double-flow solar air heater having different obstacles on absorber plates. Building and Environment 43(6): http://dx.doi.org/10.1016/j.buildenv.2007.02.016

[33] Pujol Nadal R, Martínez Moll V. (2014). Optical characterization of a fixed mirror solar concentrator prototype by the ray-tracing procedure. Journal of Renewable and Sustainable Energy 6(4): 043105. http://dx.doi.org/10.1063/1.4890219

[34] Martinez-Rodriguez G, Fuentes-Silva AL, Picon-Nunez M. (2018). Targeting the maximum outlet temperature of solar collectors. Chemical Engineering Transactions 70: 1567-1572. https://doi.org/10.3303/CET1870262

[35] Alam T, Kim MH. (2017). Performance improvement of double-pass solar air heater - A state of art of review. Renewable and Sustainable Energy Reviews 79(Supplement $\quad$ C): 779-793. https://doi.org/10.1016/j.rser.2017.05.087

[36] Karoua H, Debbache M, Takilalte A, Mahfoud O, 
Moummi A, Moummi N, Aoues K. (2016). An experimental study of a new solar air heater with a linear fresnel reflector. International Renewable and Sustainable Energy Conference (IRSEC), pp. 104-108. https://doi.org/10.1109/IRSEC.2016.7983949

[37] Sing CKL, Lim JS, Walmsley TG, Liew PY, Goto M. (2018). Effect of solar utility temperature to costing and design parameters of integrated solar thermal system. Chemical Engineering Transactions 70: 139-144. https://doi.org/10.3303/CET1870024

[38] Chouksey VK, Sharma SP. (2016). Investigations on thermal performance characteristics of wire screen packed bed solar air heater. Solar Energy 132(Supplement $\quad$ C): 591-605. https://doi.org/10.1016/j.solener.2016.03.040

[39] Bekele A, Mishra M, Dutta S. (2014). Performance characteristics of solar air heater with surface mounted obstacles. Energy Conversion and Management 85(Supplement 603-611. https://doi.org/10.1016/j.enconman.2014.04.079

[40] Labed A, Moummi N, Benchabane A, Aoues K, Moummi A. (2012). Performance investigation of singleand double-pass solar air heaters through the use of various fin geometries. International Journal of Sustainable Energy 31(6): 423-434. http://dx.doi.org/10.1080/14786451.2011.590899

[41] Youcef-Ali S. (2005). Study and optimization of the thermal performances of the offset rectangular plate fin absorber plates, with various glazing. Renewable Energy 30(2): 271-280 http://dx.doi.org/10.1016/j.renene.2004.04.009

[42] Mahfoud O, Moummi A, Kadja M, Moummi N, Mebrouk R. (2015). Dynamic and thermal study of air flow control by chicanes with inclined upper parts in solar air collectors. International Journal of Sustainable $\begin{array}{lll}\text { Energy } & 34(2) \text { : }\end{array}$ http://dx.doi.org/10.1080/14786451.2013.821125

[43] Varun Saini RP, Singal SK. (2007). A review on roughness geometry used in solar air heaters. Solar Energy $\quad 81(11)$ : $1340-1350$. http://dx.doi.org/10.1016/j.solener.2007.01.017

[44] Karim MA, Hawlader MNA. (2004). Development of solar air collectors for drying applications. Energy Conversion and Management 45(3): 329-344. https://doi.org/10.1016/S0196-8904(03)00158-4

[45] Labed A, Moummi N, Benchabane A. (2012). Experimental investigation of various designs of solar flat plate collector: Application for the drying of green chili. Renewable and Sustainable Energy 4: 043116-15. http://dx.doi.org/10.1063/1.4742337

[46] Youcef-Ali S. (2001). Étude numérique et expérimentale des séchoirs solaires indirects à convection forcée. Energetic, Univ. of Valenciennes et de HainautAmbresis, $\mathrm{N}^{\circ}$ d'order 01-05.

[47] Duffie JA, Beckman WA. (2013). Solar engineering of thermal processes. John Wiley \& Sons.

\section{NOMENCLATURE}

a

A

b

C height of artificial roughness (m) surface area of the rectangular duct $\left(\mathrm{m}^{2}\right)$ space between artificial roughness $(\mathrm{m})$ length of artificial roughness (m) specific heat of air $\left(\mathrm{J} \mathrm{kg}^{-1} \mathrm{~K}^{-1}\right)$

solar concentrated energy (-)

$D$

e

$\dot{E}$

$\dot{E} x_{\text {dest }}$

$\dot{E x}$

$f$

$\mathrm{F}^{\prime}$

$\mathrm{F}_{\mathrm{R}}$

h

the hydraulic diameter of the rectangular duct

(m)

thickness of rectangular duct (m)

energy rate $(\mathrm{W})$

rate of irreversibility $(\mathrm{W})$

exergy rate $(\mathrm{W})$

efficiency factor of solar collector (-)

$F_{R} \quad$ heat removal factor of solar collector (-)

convection heat transfer coefficient between

the absorber plate and air convection heat

transfer coefficient between the absorber plate and air $\left(\mathrm{W} \mathrm{m}^{-2} \mathrm{~K}^{-1}\right)$

I

$\mathrm{L}$

solar global irradiance incident on Linear

Fresnel Reflector $\left(\mathrm{W} \mathrm{m}^{-2}\right)$

$\mathrm{L} \quad$ length of the rectangular duct

$l$

$\dot{\mathrm{m}}$

$\mathrm{M}$

$\mathrm{nm}$

$\mathrm{n}$

$\mathrm{P}$

$S_{\text {cap }}$

$\mathrm{t}$

$T$

$S_{\text {cap }}$

$\mathrm{U}$

$\mathrm{U}_{\mathrm{L}}$

W

width of the rectangular duct (m)

air mass flow rate $\left(\mathrm{kg} \mathrm{s}^{-1}\right)$

mass $(\mathrm{kg})$

number of mirrors

number of artificial roughness

pressure (bar)

surface area of the Linear Fresnel Reflector

$\left(\mathrm{m}^{2}\right)$

time (h)

temperatures $\left({ }^{\circ} \mathrm{C}\right)$

collector concentration surface $\left(\mathrm{m}^{2}\right)$

represents the uncertainty of the variable.

work rate or power $(\mathrm{kW})$

Wth width of the collector (m)

\section{Non-dimensional numbers}

$\mathrm{Nu} \quad$ local Nusselt number

$\mathrm{Re} \quad$ Reynolds number

\section{Greek symbols}

$\rho$

$\alpha$

$\sigma$

$\tau_{\mathrm{v}}$

$\gamma$

$\phi_{c}$

$\phi_{l}$

$\phi_{s t}$

$\phi_{u}$

$v$

$\eta_{\text {th }}$

$\eta_{\text {exergy }}$

reflective of mirrors $(\%)$

thermal diffusivity, $\mathrm{m}^{2}$. $\mathrm{s}^{-1}$ constant of Stefan-Boltzmann $\left(\mathrm{W} \mathrm{m}^{-2} \mathrm{~K}^{-4}\right)$ optical coefficient of transmission of the glazing $0.84(\%)$

dimensionless temperature

the Concentrate solar energy (W)

the thermal losses $(\mathrm{W})$

the stored energy $(\mathrm{W})$

the useful energy gain $(\mathrm{W})$

dynamic velocity of air heater $\left(\mathrm{m}^{-2} \mathrm{~s}^{-1}\right)$

thermal efficiency

exergetic efficiency (dimensionless) focal distance $(\mathrm{m})$

\section{Subscripts}

abs absorber

art artificial roughness 


$\begin{array}{llll}\text { coll } & \text { collector } & 3 & \text { third thermocouple } \\ \mathrm{H} & \text { hydraulic } & 4 & \text { fourth thermocouple } \\ \mathrm{C},(\mathrm{ab}- & \begin{array}{l}\text { heat transfer convection between absorber plate } \\ \text { and air heater }\end{array} & \text { Acronyms } & \\ \text { fluid) } & \text { global irradiance } & \text { LCR } & \text { Local Concentration Ratio } \\ \mathrm{g} & \text { ambient temperature } & \text { LFR } & \text { Linear Fresnel Reflector } \\ \mathrm{a} & \text { heat transfer fluid (air heater) } & \text { LFRAH } & \text { Linear Fresnel Reflector Air Heater } \\ f & \text { inlet air heater temperature } & \text { HTF } & \text { heat transfer fluid } \\ f e & \text { outlet air heater temperature } & \text { CSP } & \text { Concentrator Solar Power } \\ f S & \text { first thermocouple } & \text { ORC } & \text { Organic Rankine Cycle }\end{array}$

